\title{
Effect of Aqueous Extracts From Some Plants on Alloxan - Diabetic Rats.
}

\author{
Gehan S. Moram \\ Biochemistry and Nutrition Department, College for women, Ain shams \\ University
}

\begin{abstract}
The present study aims to clarify the effect of aqueous extracts from green tea, sage (Salvia officinalis) and ginseng panax (panax quinquefolius L.) on the insulin sensitivity in the alloxanized diabetic rats. The experiment included twenty four normal male albino rats and 24 diabetic ones. They were classified into eight groups each of 6 rats. Two groups served as control (one normal and one diabetic rats) and the other groups were orally given the doses of aqueous extract for four weeks. The chemical analysis included level of blood glucose, plasma insulin, serum total cholesterol, serum triglycerides, HDL-cholesterol and LDL- cholesterol, in addition to the influence of these aqueous extracts on the liver glycogen and various enzymes of glucose metabolism (Glucose 6-phosphatase, ALT, AST and alkaline phosphatase).

The results revealed significant decrease $(\mathrm{p}<0.05)$ in blood glucose, and highly significant increase in both liver glycogen content and serum insulin level in the diabetic group treated with aqueous extracts of tested plants in this study when compared with the diabetic untreated group.

Serum lipids (triglycerides, total cholesterol, LDL- cholesterol and HDLcholesterol) and various enzymes of glucose metabolism (ALT, AST, ALP and glucose6-phosphatase) showed significant decrease in the diabetic group treated with aqueous extracts of tested plants when compared with the diabetic group. It is clear from the current data in this study that ginseng aqueous extract was the most efficient of the three tested plants.
\end{abstract}

\section{Introduction}

Diabetes is a hetrogeneous group of metabolic disorders characterized phys iologically by deficiency in insulin or insulin activity and clinically by hyper glycemia or impaired glucose tolerance and other manifestable disorders (WHO, 1994).

Several studies on enzymes involved in hepatic glucose metabolism in rats with alloxan and streptozotocin diabetes have shown well defined changes, which consist primarily of a decrease in the activity of glucokinase, hexokinase (Sheela and Augusti,1992), and an increase in the activity of gluconeogenic enzymes including aminotransferases (AST and ALT). (Tanaka et al., 1988 and Rawi et al, 1998) and glucose-6-phosphatase (Sheela and Augusti, 1992, Shibib et al., 1993).

In the last decade, more than 400 traditional plant treatments for diabetes mellitus have been recorded, but only a small of these have received scientific and medical evaluation to assess their efficacy. The most exten sively used plant additive in human 


\section{Effect of Aqueous Extracts From Some Plants}

food, onion (Allium Cepa) contains active hypoglycemic consti -tuents (Swanston Flatt et al., 1991). Garlic (Allium sativum) also contains a hypog -lycemic organic sulpher compounds (Rawi et al., 1996,1998).

Green tea is widely consumed in Asia and is the most popular beverage in Japan. Several previous studies have shown that green tea contains high levels of antioxidants - chemicals that may help ward off cell damage and possibly cancer and it may help prevent stomach cancer, and cancers of the pancreas, bladder and colon (Steele et al., 2000). Furthermore, the polyphenols in green tea extract of which epigllo catechin-3- gallate is the main consti tuent, were found to have antidiabetic activity (Gomes et al., 1995 and Broadhurst et al., 2000).

Various species of the genus salvia are used as folk remedies to treat several diseases. Salvia afficinalis (Sage ) is used is folk medicine, in the form of tea infusion, powder, syrup and inhalations as a tonic, digestive, antipasmodic, antip -hlogistive, expectorant, antiash -matic and antiseptic (Chiej, 1988).

Panax ginseng (panax quinq uefolius) is widely used in Chinese medicine for over 2000 years. It has been used for the treatment of a variety of conditions and hence considered a tonic to elevate mood and reduce fati gue (Sonnenborn and Proppert, 1990 ; Liu and Xlao, 1992). Other pharm acological properties including immun ostimulation (Kim et al., 1999), and liver protection (Lin et al., 1995; Yoshikawa et al., 1998), were also reported.

The current study was designed to compare the efficacy of green tea, sage and ginseng panax on impro vement of insulin sensitivity and bioche -mical complications of alloxanized diabetic albino rats and to suggest their probable hypoglycemic mechanisms.

\section{Material and Methods \\ Experimental animals :-}

The experiments were carried out with male albino rats (Sprague Dawley strain) weighing $200 \mathrm{gm} \pm 5$. The animals were obtained from Helwan, Cairo, Egypt. The animals were acclimatized for two weeks prior the experiments. Standard diet and water were available for animals ad libitum, and they were maintained under $12 \mathrm{~h}$ light / dark cycle at $25 \pm 2{ }^{\circ} \mathrm{C}$.

\section{Preparation of diabetic Rats :-}

Alloxan was purchased from sigma company, U.S.A. Diabetes mellitus was induced in normal healthy male albino rats (24 animals) by intraperitoneal injection of alloxan $(150 \mathrm{mg} / \mathrm{kg}$ body weight) as described by Desai and Bhide (1985).

\section{Tested plants:-}

The tested plants were green tea, sage (Salvia afficinalis ) and ginseng panax. The tested plants were used in aqueous extracts at concentration of $0.2 \mathrm{~g} / \mathrm{ml}$ by soaking these plants in boiling water, after 5 min each extract was filtered and the filtrate was fed intragastrically to rats at a temperature of $37 \pm 1{ }^{\circ} \mathrm{C}$. Control rats were administered an equ -ivalent volume of distilled water intragastrically at $37 \pm 1^{\circ} \mathrm{C}$.

\section{Experimental Design :-}

Twenty four normal male albino rats and twenty four diabetic ones, in eight groups each of 6 rats were fed on standard diet.

Two groups served as control (one normal and one diabetic group) and the other groups (3 normal and 3 diabetic) were orally given aqueous extracts of green tea, sage and panax ginseng in a 
dose of $1 \mathrm{ml} / 100$ gm body weight per day for 28 successive days. At the end of the experiment, animals were sacrificed after a short exposure to ether, bled from the abdominal artery, and the serum was separated for chemical analysis.

\section{Biochemical analysis :-}

Serum glucose concentration was estim -ated by enzymatic method of Trinder (1969)

Liver glycogen content was determined according to the method of Seifter et al (1950).

Estimation of insulin levels were carried out in National Research Center, El Dokki, Giza, according to the methods of Marschner et al., (1974).

Determination of liver transaminases enzyme activities (AST,ALT) were perf -ormed according to the method desc ribed by Reitman and Frankel (1957).

Determination of Glucose-6-phosp hatase activity was done according to the method of Swanson (1950).

Determination of alkaline phosphatase activity was done according to Belfield and Goldberg (1971).

Determination of triacylglycerol was done according to enzymatic method of Fosseti and Prencipe (1982).

Determination of total cholesterol was done according to colourimetric method of Allain et al., (1974)

Determination of LDL-cholesterol was done by enzymatic method of Steinbery (1981).

Determination of HDL-cholestrol was done by method of Arcol (1984).

\section{Statistics :-}

The data of all parameters were expressed as mean \pm SD. Statistical evaluation of data was performed using analysis of variance (ANOVA)(Winer,
1971). $\mathrm{p}<0.05$ was taken to indicate significance.

\section{Results and Discussion}

The present study showed a significant increase in blood glucose level in the alloxanized diabetic group by $(+207 \%, p<0.05)$ (Table 1), compared to that of non-diabetic ones. While the oral administration of aqueous extracts of green tea, sage and ginseng caused significant decrease by $(-14.82,-25.81$ and $-54.75 \%$ respe ctively, $\mathrm{p}<0.05)$.as compared with the diabetic control rats.

On the other hand, our study demonstrated that the normal rats that received aqueous extracts of sage and green tea showed normal insulinemia as compared with normal values while the normal rats that received aqueous extract of ginseng showed an increase in serum insulin level by $(10.86 \%, \mathrm{p}$ $<0.05$ ) ( Table 1) as compared with untreated control animal.

Alloxanized diabetic rats caused severe hypoinsulinemia by ($70.28 \%$. p <0.05) (Table 1) as compared with untreated control rats. The adminis -tration of aqueous extracts of green tea, sage and ginseng to alloxanized diabetic rats partially restored serum insulin level but to a lower value than the untreated control group $(-53.1,-32.66$ and $-4.28 \%$ respectively, $\mathrm{p}<0.05)$. By assaying the I: G ratio in Table (1), one can notice that ginseng panax extract had a high I: $G$ ratio than sage while $\mathrm{I}: \mathrm{G}$ ratio in green tea decreased and is more close to the diabetic ones.

Diabetic control rats showed depletion in liver glycogen content which was highly significant compared to the non-diabetic control. The treated rats showed a significant increase in liver glycogen by $(147,74.15$ and $55.76 \%$, for ginseng, sage and green 


\section{Effect of Aqueous Extracts From Some Plants}

tea groups respectively, $\mathrm{p}<0.05)$ (Table $1)$.

As insulin and glycogen are parallel to each other, one can notice that, with the high depeletion of insulin in diabetic rats, there was a high depletion in glycogen concentration. The recovery of insulin was high with ginseng treatment followed by sage and green tea, also the recovery in liver glycogen was high in ginseng, sage and green tea treated groups respectively (Table 1).

Effect of aqueous extracts of tested plants on serum ALT, AST, glucose -6-phosphatase and alkaline phosphatase activities is presented in Table (2).

Aqueous extracts of sage and ginseng did not alter significantly the ALT activity in normal control rats $(\mathrm{p}<$ 0.05 ) except green tea extract which recorded a mild increase (12.5\%), meanwhile alloxanized diabetic rats induced a highly significant increase in ALT activity by $(93.46 \%, \mathrm{p}(<0.05)$ as compared with normal control ones. The administration of aqueous extracts of green tea, sage and ginseng to alloxanized diabetic rats significantly improved the ALT activity by $(-25.73$, 37.41 and $-42.23 \%$, respectively, o < $0.05)$ as compared to normal diabetic group (Table 2).

Also, oral administration of aqueous extracts of tested plants to normal groups had no significant effect on the AST activity $(\mathrm{p}<0.05)$. However, the alloxanized diabetic rats showed highly significant increase in AST activity $(97.67 \%, \mathrm{p}<0.05)$, when comp ared with normal control group. Mean while, green tea, sage and ginseng, cau sed a significance decrease by $(-29.83$, 20.9 and $-37.68 \%, \mathrm{p}<0.05)$ lower than diabetic control group (Table 2).

Normal control rats treated with aqueous extracts of tested plants exhibited slightly significant decrease in glucose 6- phosphatase $(\mathrm{p}<0.05)$, while the diabetic group exhibited a highly significant increase when compared with normal control group. On the other hand, alloxan diabetic rats treated with green tea, sage and ginseng extracts exhibited significant change in glucose 6-phosphatase activity when compared with normal or with diabetic rats, $(\mathrm{p}<0.05)$. from Table 2 it is also found that the aqueous extracts of green tea and sage significantly increased the alkaline phosphatase activity of normal and alloxan diabetic rats ( $\mathrm{p}<0.05$ ). Meanwhile, aqueous extract of ginseng did not change significantly the alkaline phosphatase activity of normal rats but in alloxan diabetic rats ginseng extract significantly decrease the activity of alkaline phosphatase compared to untre -ated diabetic rats $(-45.57 \% \mathrm{p}<0.05)$

The present data demonst rated that alloxan diabetic rats showed marked carbohydrate metabolic distrurb -ances including servere hyperglycemia, hypoinsulinemia, in addition to marked decrease in liver glycogen content. Hyperglycemia can be considered as a direct reflex to the marked hypoinsu linemia caused by the selective destruc tive cytotoxic effect of alloxan on the cells of the pancreas (Bolaffi et al., 1986). Also from the biochemical point of view, it was evident that increased hepatic glucose output in diabetes mellitus may be derived either from glycogenolysis or from gluconeogensis or both (Shibib et al., 1993, Rawi et al., 1996). This evidence was confirmed by our results which showed an enormous depletion of liver glycogen in the diabetic rats and a marked increase of the detected gluconeogenic serum enzymes, ALT and AST and liver glucose 6-phosphatase as compared with that of the non diabetic ones. Moreover, the depletion of liver 
glycogen of diabetic rats in the present study was attributed to loss of glycogen synthetase activiting system (Chang and Johnson,1980 ; Rawi et al., 1998), and increased glucose 6- phosphatase as demonstrated in the present study. Thus, both high rates of gluconeogensis and glycogenolysis are consistent with the observed hyperglycemia of the diabetic rats in the present work.

Our study demonstrated that the oral administration of aqueous extracts of green tea, sage and ginseng caused marked amelioration of serum glucose concentration of alloxan diabetic rats, besides elevating insulin concentration and increasing liver glycogen content which was reduced by alloxan admini stration. Our data were is good agreem ent with other investigators (Marles and Farnsworth , 1995 and Abdel- Moneim, 1998, Broadhurst et al, 2000)who stated that the positive effects of specific plant extracts on insulin activity suggest a possible role of these plants in impro ving glucose and insulin metabolism.

The glucose 6-phosphatase is a specific enzyme present in the liver and kidney but absent from muscles and adipose tissue. It is mainly responsible for releasing the glucose molecules to the blood by converting glucose 6 - phos -phate to glucose ( Murray et al., 1996).

The present results indicated that the elevated liver glucose 6- phosp -hatase activity of diabetic rats showed a significant decrease after treatment with tested plants and ginseng extract appeared to have the greatest effect. Consistent with the depressing effect of tested plants on glucose 6- phosphatase activity are the data of other glucone ogenic enzymes, alanine aminotransfe rase (ALT) and aspartate aminotran sferase (AST) activities which were also depressed. These results are in accord ance with those of Rawi et al. (1998), who found that the decrease of transa - minase activities with treatments may be attributed to the improved liver function with return of gluconeogensis towards its normal rate.

Concerning the effect of alloxan diabetes on alkaline phosphatase (ALP) activity, the data obtained revealed a significant increase in this group. The elevated activity, however, was reduced by aqueous extracts of tested plants. In agreement with the present results, Defronzo, (1999) and Roy et al., (1998) showed a slight increase of ALP activity after induction of diabetes by alloxan. Moreover, Roy et al. (1998) and Vuksan et al. (2000) reported that alloxan diabetes exerted 2 fold increase in serum ALP activity and the treatment of the diabetic animal with ginseng or insulin caused a marked decrease in the elevated enzyme. This indicates that insulin has a role in regulating the activity of this enzyme.

Several previous studies have shown that the hypoglycemic effect of green tea was attributed to the presence of Catechins and water soluble polysa ccharide fraction (Matsumoto et al., 1993 and Gomes et al., 1995).

Broadhurst et al. (2000) suggested that green tea extract possibly protect the $s$ - cells from the toxic effect of STZ and also help regeneration of the damaged cell.

Marles et al. (1995) found that volatile oil of Salvia officinalis (sage) produced significant hypoglycemic effects in alloxan diabetic mice. The antidiabetic effect of Salvia officinalis extract was attributed to the presence of cetain flavonoides such as kaempferol, luteolin and quercetin which contain chorman ring (Wang et al ., 2000) .more -over the antihyperglycemic effect may be also attributed to the chromium content which primarily acts as a component of glucose tolerance factor, (Chaney, 1993). 


\section{Effect of Aqueous Extracts From Some Plants}

The reductions in serum glucose concentration by ginseng may be due to one or a combination of different mech -anisms, including modulation of dige stion, insulin sensitivity, or insulin secretion (LIU et al., 1992). This is in agreement with the present study where the plasma insulin and serum glucose were significantly decreased after ginse -ng treatment in the alloxanized diabetic rats.

Ginseng has been shown to inhibit gastric secretion in rats (Suzuki, et al., 1991) and to decrease glucose and maltose absorption in rat and human (Onomura et al., 1999). Also, ginseng was reported to slow digestion, so low levels of blood glucose were recorded (Vuksan et al., 2001). Furthermore, Wolever (1998) found that both of which operate through delaying or inhibiting the absorption of carbohy drates in the gut.

Aitelle et al., (1994) found that the effect of ginseng in lowering blood glucose level in STZ- diabetic rats is probably attributed to the insulin like components present in the plant.

Active components of ginseng that may have an important mediating role in the hypoglycemic processes include its polysaccharide (ginsenans), peptidoglycan (panaxans), and ginseno side profiles. Most pharmacological actions of ginseng, however, are attribu -ted to the involvement of ginsenosides (Kim et al. (1999).

Yoshikawa et al. (1998) stated that ginseng fractions isolated from ginseng roots such as ginseng polysaccharides or polypeptides reduced blood glucose level and stimulated the release of insulin. They suggested that ginseng increases carbohydrate utilization and promotes aerobic oxidation course.

Attele et al.(1994)suggested that the antidiabetic action of ginseng fraction may be partially mediated through a decrease in hepatic gluconeogensis by suppressing the activity of key glucog enic enzymes.

Also, ginseng has been shown to increase glucose- transporter -2 protein in the livers of normal and hypergl ycemic mice (Ohnishi et al., 1996), and glucose uptake into sheep erythrocytes in a dose dependent manner (Hasegawa et al., 1994).

Recent studies have shown that total ginsenosides affect the cholinergic dopaminergic (Vuksan et al., 2000) and adrenergic systems in rodents (Kim et al., 1998; kim et al., 1999). Roy et al.(1998)found that insulin -stimulated glucose uptake in rat skeletal muscles and adipose tissue is nitric oxide dependent. Evidence suggests that the increase in nitric oxide capable of elucidating this response might be accomplished by ginseng. Enhanced nitric oxide synthesis by ginseng in endothelium of lung, heart and kidney and in the corus cavernosum has been noticed (Gillis, 1997). This effect may also be mediated by nitric oxide which stimulates glucose - dependent secret ion of insulin in rat islet cells (Spinas et al., 1998).

Moreover, our study was run to evaluate the effect of aqueous extracts of tested plants on lipid profile in the normal and alloxan diabetic rats.

The data on serum triacylg lycerol, total cholesterol HDL and LDL cholesterol concentrations as well as HDL / total and LDL/ HDL cholesterol ratios are given in table (3). Serum trglycerides were not affected by the administration of aqueous extracts of the tested plants to normal rats as compared with control group $(p>0.05)$ whereas alloxanized diabetic rats showed marked hypertriglyceridemia by (+57.89\%, p<0.05). Meanwhile, green tea, sage and ginseng intake to diabetic rats caused a significant decrease by 
$(-14.19, \quad-21.47$ and $-29.88 \%$ respectively $\mathrm{p}<0.05)$ lower than the diabetic values. On the other hand green tea, sage and ginseng extracts intake to normal rats did not affect either total cholesterol or LDL - cholesterol levels which were comparable to those of normal control values. A marked significant elevation was detected for both tested parameters in alloxan diabetic rats by $(+30.19 \%, \mathrm{p}<0.05) \&$ $(71.96 \%, \mathrm{p}<0.05)$ respectively as compared with the normal control group. Both total cholesterol \& LDLcholesterol were regulated to normal values by aqueous extracts of tested plants in the alloxan diabetic rats. Meanwhile, values of high density lipoprotein (HDL) cholesterol were found to be significantly increased in normal treated groups when compared with normal control ( $\mathrm{p}<0.05$ ), while alloxan diabetic rats recorded a highly significant decrease when compared to normal control group (-37.27\%, p < 0.05 ). Treatment with plant extracts caused a significant increase in HDL cholesterol when compared with diabetic control group (26.71, 42.82 and $46.45 \%, \mathrm{p}<0.05)$.

Table (3), also shows that in alloxan diabetes there was a significant decline in HDL / total cholesterol ratio $(-52.2 \%, \mathrm{p}<0.05)$ compared to normal control group Interestingly, the plant extracts significantly HDL / total cholesterol ratios compared to diabetic control group. On the contrary, LDL / HDL cholesterol ratio was markedly elevated in alloxan diabetic rats when compared with untreated control rats (174.23\%, p <0.05). Moreover, tested plants significantly reduced such elevated ratio in the alloxan diabetic rats to reach levels comparable with untreated normal group.
In the present work alloxan diabetic rats exhibited marked hypertri glyceridmia, hypercholesterolemia with concomitant decrease in HDL choles terol as well as alteration in HDL / total and LDL / HDL cholesterol ratios. Our results are in accordance with the findings of Mathe (1995), Ulicna, et al. 1996) and Wasan et al. (1998)who recor -ded marked increases of serum triglyce -rides and cholesterol levels and abnorm -alities in lipoprotein levels in alloxan and streptozotocin diabetic animals. These abnormalities certainly play a role in the increased risk for cardio vascular disease (Tsutsumi et al., 1995).

Treatments of alloxan diabetic rats in the present study with green tea, sage and ginseng produced marked decreases of serum triglycerides, total cholesterol concentrations; and also elevated HDL / cholesterol and reduced LDL / HDL ratios to reach normal values. These observations indicate that the hypocholesterolemic action of the tested plants is attributed to the ability to suppress cholesterol biosynthesis. Furthermore, correlation between insu lin levels, triglycerides and cholesterol fractions underline the important role of the hormone in the control of blood lipid levels. Indeed hepatic VLDLtriglyceride synthesis and secretion are regulated by insulin (Marles and Faresworth, 1995).

In agreement with our results, Roy et al. (1998) and Yoshikawa et al., (1998) reported that ginseng extract or its fraction such as saponins have pronounced antilipemic properties.

In conclusion, this study calls attention to the need of further bioche mical investigation of the plants' constituents and invites collaboration in the development of clinical field studies to access the efficacy of the herbalist use of medicinal plants in the treatment of diabetes. It is clear from the pre 
mentioned reports that green tea, sage and ginseng have numerous antidiabetic effects like decreasing serum glucose concentration, increasing serum insulin levels and improving metabolic pathways of lipids and that ginseng aqueous extract was the most effective of the three tested plants.

\section{References}

1. ABDEL-MONEIM, A. (1998) : Effect of some medicinal plants and gliclazide on insulin release in vitro.J. Egypt. Ger. Soc. Zool., 25 : 423- 445.

2. ALLAIN, C. C.; POON, L.S.; CHAN, C. S.; RICHMOND, W. AND FU,P. C. (1974) : Enzymatic determination of serum cholesterol. Clin. Chem., 20 (4) : 470- 475.

3 . ARCOL, (1989): Separation of high density lipoproteins and determination of cholesterol and phospholipids bound to these fractions European Atherosclerosis Society, European Heart J. ,15 : 121-124.

4. ATTELE, A.; WU, J. A. AND YUAN, C.S.(1999) : Ginseng pharmacology multiple constituent and multiple actions. Biochem. Pharmacol.58:1685 -1693.

5. BELFIELD, A. AND GOLDBERG, D.M. (1971): Revised assay for serum phenyl phosphatase activity using 4- amino - antipyrine. Enzyme, 12 (5)561576.

6. BOLAFFI, J. L. ; NOWLAIN R.E.; GRUZ, L. AND GRODSKY, G.M. (1986) :Progressive damage of cultured pancreatic islets after single early exposure to streptozotocin. Diabetes, 35 : 1027-1033.

7. BROADHURST, C. L.; POLANSKY, M.M.AND
ANDERSON, R.A. (2000) : Insulinlike biological activity of culinary and medicinal plant aqueous extracts in vitro. J.Agric.food chem. $48: 849-852$.

8. CHANEY, S. G. (1993) : Pprinciples of nutrition II : Micronutrient in : textbook of biochemistry with clinical correlations. Delving, T. M. editor, ( $3^{\text {rd }}$ edition) A. John, Wiley and sons, INC. pupil- Singapore, pp.: 1138.

9. CHANG, M.W. AND JOHNSON, M.A. (1980): Effect of garlic on carbohydrate metabolism and lipid synthesis in rats. J. Nutrition, 110: 931-936.

10. CHIEJ, R.(1988) : Mac Donald Encyclopedia of medicinal plant. Mac Donald \&Co.(publishers) LTD, London, pp. 271.

11. DEFRONZO, R. A.(1999): pharmacologic therapy for type 2 diabetes mellitus. Arch. Intern. Med.131 :281- 303.

12. DESAI, A.C. AND BHIDE, M.B.(1985) : Hypoglycaemic activity of Hamiltonia suaveolens. Indian J.Med. Res., 81: 86-91.

13. FOSSETI, P. AND PRENCIPE, L.(1982) : Enzymatic determination of triglycerides. Clin. Chem.. 28: 2077.

14. GILLIS, C. N. (1997) : Panax ginseng pharmacology : a nitric oxide link. Biochem. Pharmacol.54 $: 1-8$.

15. GOMES, A. ; VEDASIROMONI, J.R.; DAS, M., SHARMA, R.M. AND GANGULY, D.K. (1995) : Anti- hyperglycemic effect of black tea (Camellia sinensis) in rat. Journal of Ethnoph armacology 45 :223- 226.

16. HASEGAWA, H.; MATSUMIYA, S. MURAKAMI, C.; KUROKAWA, T. ; KASAL, R.; 
ISHIBASHI, S.AND YAMASAKI, K.(1994) : Interactions of ginseng extract, ginseng separated fractions, and some triterpenoid saponins with glucose transporters in sheep erthrocytes. Planta Md. 60 :153-157. 17. KIM, H.S.; LEE, J. H.; GOO, Y.S AND NAB, S. Y. (1998) : Effect of ginsenosides on $\mathrm{Ca}^{+2}$ channels and membrane capacitance in rat adrenal chromaffin cells. Brain res. Bull. 46: 245-251

18. KIM, H.S.; KIM,K.S. AND OH, K.W.(1999) : Inhibition by ginsenoides Rbland $\mathrm{Rg} 1$ of cocaine induced hyperactivity, conditioned place preference, and postsynaptic dopamine receptor super-sensitivity in mice. Pharmacol Biochem Behav $63: 407-412$.

19. LIN, J.H., WU, L.S.;TSAI, K.T.; LEU,S.P.; JEANG,Y.F.AND HSIEH, M.T.(1995) :Effect of ginseng on the blood chemistry profile of dexamethasone-Treated male rats. Am. J. chin Med. 23 : 167-172.

20. LIU, C.X. AND XLAO, P.G. (1992) : Recent advances on ginseng research in China. J. Eethanopharmacol, $36:$ 27-38.

21. MARLES, R.J. AND FARNS WORTH, N. R. (1995) : antidiabetic plants and their active constituents. Phytomedicine, 2 (2) : 137-189.

22. MARSCHNER, I BOTTERMANN, P.; ERHARDT, F:, LINKE, R.; MAIER, V., SCHWANDT, P.; VOGT, W. AND SCRIBA, P.C. (1974) : Group experiments on the radioimmunological insulin determination. Horm. Metab. Res.,6 : 293-296.

23. MATHE, D. (1995) : dyslipid -emia and diabetes animal models. Diabet. Metab. 21 (2) : 106-111.
24. MATSUMOTO, N.; ISHIGAKI, F. ; ISHIGAKI, A.; IWASHINA, H. AND HARA, Y. (1993) : Rduction of blood glucose levels by tea catechin. Bioscience Biotechnology and Biochemistry. 57 :525- 527.

25. MURRAY, R.K.; GRANNER, D.K ; MAYERS, P.A. AND RODWEU V.W. (1996) : Harper's biochemistry 24th ed. Application and lange p.p. 195-196.

26. OHNISHI, Y.; TAKAGI, S. ; MIURA, I.; USAMI, M.; KAKO, M.; ISHIHARA, E.; YANO TANIGAWA, K. AND SEINO, Y. (1996) : Effect of ginseng radix on GLUT2 protein content in mouse liver in normal and epinephrineinduced hyperglycemic mice. Biol. Pharm. Bull. 19 : 1238-1240.

27. ONOMURA, M.; TSUKADA, H.; FUKUDA, K.; ILOSOKAWA, M. ; NAKAMURA, H.; KODAMA, M.; OHYA, M. AND SEINO, Y. (1999) : Effects of ginseng radix on sugar absorption in small intestine. Am. J. chin. Med.27 : 347 -354.

28. RAWI, S. M.; ABDELMONEIM, A. AND AHMED O. M. (1998) : Studies on the effect of garlic oil and glibenclamide on alloxan diabetic rats. Egypt. J. ZOOL., 30 211-228.

29. REITMAN, S. AND FRANKEL, S. (1957) : A clourimetric method for the determination of serum glutamic oxaloacetic and glutamic pyruvic transaminases. Am. J. Clin. Path., $28: 56-65$.

30. ROY, O.; PERRAULT,M. AND MAREFFE, A. (1998) : Insulin stimulation of glucose uptake in skeletal muscle and adipose tissue in vivo is no 


\section{Effect of Aqueous Extracts From Some Plants}

dependent. Am. J. Physiol. 274 : E 692 : E 699.

31. SEIFTER, S.; DAYTON, S.; NOVIC, B. AND MUNTWYLER, E. (1950) : The estimation of glycogen with anthrone reagent. Arch. Biochem., 25 : 191-200.

32. SHEELA, C. G. AND AUGUSTI, K.T. (1992) : Antidiabetic effect of $\mathrm{S}-$ allyl cystein sulphoxide isolated from garlic, Allium sativum linn. Ind. J. Exp. Biol.. 30 : 523-526.

33. Shibib, B. A. KHAN,L.A. AND RAHMAN, R. (1993) : Hypoglycemic activity of coccinia indica and Momordica charantia : depression of the hepatic gluconeo genic enzymes ; glucose 6- phosp hatase and fructose 1,6- biphosp hatase and elevation of both liver and red cell shunt enzyme glucose 6- phosphate dehydroge -nase. Biochem. J., 292 : 267-270.

34. SONNENBORN, U. AND PROPPERT, Y.(1990) ; Ginseng ( Panax ginseng C. A. Mayer) Zeitschrift Fur phytotherpie. $11: 35-49$.

35. SPINAS, G. A.; LATFRANCHI, R. ; PRANCOY, I.; DAVID RICHTER, C. And REINECKE, M.( 1998) : The early phase of glucose- stimulated insulin secretion requires nitric oxide Diabetologia 41 :292-299.

36. STEELE, V.E.; KELLOFF, G.J.; BALENTINE, D. ; BOONE, C.W.; MEHTA, R.; BAGHERI, D.; SIGMAN, C.C.; ZHU, S. AND SHARMA, S. (2000) : comparative chemopreventive mechanisms of green tea, black tea and selected polyphenol extract measured by in vitro bioassays. Carcinogenesis, 21 : $63-67$.

37. STEINBERG, D. (1981) : Metabolism of lipoproteins at the cellular level in relation to atherogenesis. In lipoproteins, ather -osclerosis and cornary heart disease. Elsevier. North Holnd 1 (2) : 31-48.

38. SUZUKI, Y.; ITO, Y.; KONNO, C. AND FURUY, A. (1991) : Effects of tissue cultured ginseng on gastric secretion and pepsin activity Japanese. Yakugaku zasshi, 111 : 770-774.

39. SWANSON, M. A.; WAKE, FOREST COLL AND NISTONSALEM, N.C. ( 1950 ) : phosp hatase of liver glucose- 6-phosp hatase. J. Biol. Chem. 184 : 647659.

40. SWANSTON-FLATT, S. K.; FLATT, R.R.; DAY, C. AND BAILEY, C. J. ( 1991) : Traditional dietary adjunts for treatment of diab -etes. Proc. Nutr. Soc. 50 :641-651.

41. TANAKA, K.; NANBARA, S.; TANAKA, T.; KOIDE, H. AND HAYSHI, T. (1988) : aminotran ferase activity in the liver of diabetic mice. Diabetic Res. Clin. Pract., 5 (1) : 71-75.

42. TRINDER, P.(1969) : Enzymatic method of glucose determination in serum Ann. Clin. Biochem., 6 : 24.

43. TSUTSUMI, K.; INOUE, Y.; SHIMA,A. AND MURASE, T. (1995) : Correction of hypertriglyc eridemia with low high- density lipoprotein cholesterol by the novel compound No. 1886, a lipoprotein lipase- promoting agent, in STZinduced diabetic rats. Diabetes, 44 : 414- 417.

44. ULICNA, O.; VOLKOVOVA, K. AND ISTVANOVA, B. (1996). Bioenergetics of liver mitochondria in rats in experimental insulindependent diabetes Bratisl. Lek.listy, 97 (10) : 619-624. 
45.

VUKSAN,

$\mathrm{V}$.

SIEVENPIPER, J. ; KOO, V.Y.Y.; FRANCIS, T. ,BELJANZDRAVKOVIC, U.; XU,Z. AND VIDGEN, E. (2000) : American ginseng panax quinquefolius L ) Reduces Postpran -dial Glycemia in nondiabitic subjects and subjects with type 2 Diabetes $M$ ellitus. Archives of internal medicine 160 :1009 -1013.

46. VUKSAN, V.;STAVRO, M.P; SIEVENPIPER, J.; BELJANZDRAKOVIC, U.; LEITER, L.A.; JOSSE, R.G. AND XU, Z. (2000) : Similar postprandial Glycemic reductions with Escalation of dose and Administration Time of diabetis Care, 23 :1221- 1226.

47. VUKSAN, V.; SIEVENPIPER, J.; WONG, J.; XU,Z.; BELJAN-ZDRAVKOVIC, U.; ARNASON, J.; ASSINEWE, V.; STAVRO, M.; JENKINS, A.; LEITER, L.AND FRANCIS, T. (2001) : American ginseng (panax quinquefolius L.) attenenuatis postprandial glycemia in a timedependent but not dose-dependnt manner in healthy individuals. American Journal of clinical Nutrition, $73: 753-758$.

48. WANG, M.; KIKUZAKI, H.; ZHU, N.; SANG, S.; NAKATANI, N. AND HO, C.T. (2000) : Isolation and structural elucidation of two new glycosides from sage (Salvia, officialis L.). J. Agric. Food Chem, $48: 235-238$.

49. WASAN, K. M.; NG, S. P. ; WONG, W. AND RODRIGUES, B.B. (1998) : streptozotocin and alloxan- induced diabetes modifies total plasma and lipoprotein lipid concentration and composition without altering cholesteryl ester transfer activity. Pharmacol. Toxicol.,83 : $169-175$.

50. WHO (1994) : prevention of diabetes mellitus. Technical Report series 844, pp. 11-15, 21, 27. Geneva, Switzerland.

51. WINER, B.J. (1971) ; S tatistical principles experimental design.Mc Graw- Hill, New York,

52. WOLEVER, T. M. ( 1998) :

Assessing the, antihyperglycemic effect of acarbose : solid or liquid test meal. Diabetes care. 21 :667668.

53. YOSHIKAWA, M. ; MURAKAMI,T. AND YASHIRO, K. ( 1998) : Bioactive saponins and glycosides, XI : structures of new dammarane- type triterpene oligoglycosides, quinquenosides I, II, III, IV and V, from American ginseng roots of panax quinquefolium L. Chem Pharm Bull. 46 : 647- 654. 
Effect of Aqueous Extracts From Some Plants

Table (1) Change in various biochemical parameters in serum and liver of normal, alloxan diabetic and alloxan diabetic treated rats for 4 weeks

\begin{tabular}{|c|c|c|c|c|c|c|c|c|c|c|}
\hline \multirow{2}{*}{$\begin{array}{l}\text { parameter } \\
\text { Plant }\end{array}$} & \multicolumn{2}{|c|}{ Serum glucose (mg /dl) } & \multicolumn{2}{|c|}{$\begin{array}{l}\text { Liver glycogen content } \\
(\mathrm{mg} / \mathrm{g})\end{array}$} & \multicolumn{2}{|c|}{$\begin{array}{c}\text { Serum insulin level }(\mu \\
\mathrm{IU} / \mathrm{ml})\end{array}$} & \multicolumn{2}{|c|}{$\mathrm{I} / \mathrm{G}$} & \multicolumn{2}{|c|}{ I/Gn. } \\
\hline & $\mathrm{N}$. & A.D. & N. & A. D. & $\mathrm{N}$. & A.D. & N. & A.D. & N. & A.D. \\
\hline Control & $\begin{array}{l}85.76^{\mathrm{a}} \\
\pm 2.9 \\
\end{array}$ & $\begin{array}{l}263.97 \\
\pm 8.71\end{array}$ & $\begin{array}{l}13.66^{\mathrm{a}} \\
\pm 0.59\end{array}$ & $\begin{array}{r}4.68 \\
\pm 0.54\end{array}$ & $\begin{array}{l}26.42^{\mathrm{ab}} \\
\pm 2.09\end{array}$ & $\begin{array}{r}7.85 \\
\pm 0.72\end{array}$ & 0.31 & 0.03 & 1.93 & 1.68 \\
\hline Green tea & $\begin{array}{l}91.53^{\mathrm{a}} \\
\pm 4.78 \\
\end{array}$ & $\begin{array}{l}224.83 \\
\pm 5.29 \\
\end{array}$ & $\begin{aligned} & 12.63^{\mathrm{D}} \\
& \pm 0.063 \\
&\end{aligned}$ & $\begin{array}{r}7.43 \\
\pm 0.54 \\
\end{array}$ & $\begin{array}{l}25.47^{0} \\
\pm 2.64 \\
\end{array}$ & $\begin{array}{r}13.39 \\
\pm 0.74 \\
\end{array}$ & 0.28 & 0.06 & 2.02 & 1.80 \\
\hline Sage & $\begin{array}{l}86.65^{\mathrm{a}} \\
\pm 4.74 \\
\end{array}$ & $\begin{array}{l}195.84 \\
\pm 4.52 \\
\end{array}$ & $\begin{array}{l}12.82^{\mathrm{b}} \\
\pm 0.71 \\
\end{array}$ & $\begin{array}{r}8.15 \\
\pm 0.27 \\
\end{array}$ & $\begin{array}{l}27.27^{\mathrm{a}} \\
\pm 0.53\end{array}$ & $\begin{array}{r}17.79 \\
\pm 0.83 \\
\end{array}$ & 0.31 & 0.09 & 2.13 & 2.18 \\
\hline Ginseng & $\begin{array}{l}85.39^{\mathrm{a}} \\
\pm 3.35\end{array}$ & $\begin{array}{l}119.44 \\
\pm 4.35\end{array}$ & $\begin{array}{l}13.78^{\mathrm{a}} \\
\pm 0.68\end{array}$ & $\begin{array}{r}11.56 \\
\pm 0.58\end{array}$ & $\begin{array}{l}29.29 \\
\pm 1.57\end{array}$ & $\begin{array}{l}25.29^{\circ} \\
\pm 0.66\end{array}$ & 0.34 & 0.21 & 2.13 & 2.19 \\
\hline L.S. D P<0.05 & \multicolumn{2}{|c|}{6.2648} & \multicolumn{2}{|c|}{0.67912} & \multicolumn{2}{|c|}{1.6677} & & & & \\
\hline L.S. D P<0.01 & \multicolumn{2}{|c|}{8.4082} & \multicolumn{2}{|c|}{0.9086} & \multicolumn{2}{|c|}{2.2313} & & & & \\
\hline
\end{tabular}

$\mathrm{N}$ : Normal A.D. : Alloxan Diabetic

Values given as mean of 6 rats \pm SD.

Means with the same letter are not significantly different.

I /G : ratio between Insulin level and glucose

I / Gn : ratio between insulin level and glycogen content.

Table (2) Change in various enzymes activity in serum and liver of normal, alloxan diabetic and alloxan diabetic treated rats for 4 weeks

\begin{tabular}{|c|c|c|c|c|c|c|c|c|}
\hline \multirow{2}{*}{$\begin{array}{c}\text { parameter } \\
\text { Plant }\end{array}$} & \multicolumn{2}{|c|}{$\begin{array}{l}\text { Liver G-6-pase activity ( } \\
\mu \mathrm{mol} \text { pi /min /g protein) }\end{array}$} & \multicolumn{2}{|c|}{$\begin{array}{c}\text { Serum ALT activity } \\
(\mathrm{U} / \mathrm{L})\end{array}$} & \multicolumn{2}{|c|}{$\begin{array}{c}\text { Serum AST activity } \\
(\mathrm{U} / \mathrm{L})\end{array}$} & \multicolumn{2}{|c|}{$\begin{array}{c}\text { Serum ALP activity } \\
(\mathrm{U} / \mathrm{dl})\end{array}$} \\
\hline & $\mathrm{N}$. & A.D. & N. & A. D. & $\mathrm{N}$. & A.D. & $\mathrm{N}$. & A.D. \\
\hline Control & $\begin{array}{r}22.79 \\
\pm 0.49\end{array}$ & $\begin{array}{l}35.21 \\
\pm 1.74\end{array}$ & $\begin{array}{l}24.47^{\mathrm{DC}} \\
\pm 1.38\end{array}$ & $\begin{array}{r}47.34 \\
\pm 1.58\end{array}$ & $\begin{array}{l}43.39^{a} \\
\pm 3.48\end{array}$ & $\begin{array}{l}85.77 \\
\pm 3.17\end{array}$ & $\begin{array}{c}39.32^{D} \\
\pm 1.5\end{array}$ & $\begin{array}{l}84.94 \\
\pm 2.88\end{array}$ \\
\hline Green tea & $\begin{array}{l}21.06^{\mathrm{a}} \\
\pm 1.64\end{array}$ & $\begin{array}{l}29.04 \\
\pm 0.87\end{array}$ & $\begin{array}{l}27.53^{\mathrm{a}} \\
\pm 1.29\end{array}$ & $\begin{array}{l}36.65 \\
\pm 2.25\end{array}$ & $\begin{array}{l}44.78^{\mathrm{a}} \\
\pm 1.05\end{array}$ & $\begin{array}{l}60.18 \\
\pm 2.38\end{array}$ & $\begin{array}{l}46.14^{\mathrm{a}} \\
\pm 1.17\end{array}$ & $\begin{array}{l}53.65 \\
\pm 1.53\end{array}$ \\
\hline Sage & $\begin{array}{l}20.54^{\mathrm{a}} \\
\pm 1.01\end{array}$ & $\begin{array}{l}26.36 \\
\pm 0.76\end{array}$ & $\begin{array}{l}25.61^{D} \\
\pm 0.95\end{array}$ & $\begin{array}{l}29.63 \\
\pm 1.37\end{array}$ & $\begin{array}{l}44.12^{\mathrm{a}} \\
\pm 1.95\end{array}$ & $\begin{array}{r}67.84 \\
\pm 2.24\end{array}$ & $\begin{array}{r}-1.84 \\
+24.85\end{array}$ & $\begin{array}{r}65.34 \\
+1.84\end{array}$ \\
\hline Ginseng & $\begin{array}{r}17.83 \\
\pm 0.64\end{array}$ & $\begin{array}{l}24.64 \\
\pm 1.59\end{array}$ & $\begin{array}{l}23.18^{\mathrm{C}} \\
\pm 1.11\end{array}$ & $\begin{array}{l}27.35^{\mathrm{a}} \\
\pm 1.5\end{array}$ & $\begin{array}{l}42.88^{\mathrm{a}} \\
\pm 0.89\end{array}$ & $\begin{array}{r}-5.45 \\
\pm 1.39\end{array}$ & $\begin{array}{l}40.85^{\circ} \\
\pm 1.55\end{array}$ & $\begin{array}{l}46.23^{\mathrm{a}} \\
\pm 1.19\end{array}$ \\
\hline L.S. $D P<0.05$ & \multicolumn{2}{|c|}{1.3830} & \multicolumn{2}{|c|}{1.7193} & \multicolumn{2}{|c|}{2.6252} & \multicolumn{2}{|c|}{2.1257} \\
\hline L.S. $D P<0.01$ & \multicolumn{2}{|c|}{1.8504} & \multicolumn{2}{|c|}{2.3004} & \multicolumn{2}{|c|}{3.5124} & \multicolumn{2}{|c|}{28441} \\
\hline
\end{tabular}

$\mathrm{N}$ : Normal A.D. : Alloxan Diabetic

Values given as mean of 6 rats \pm SD.

Means with the same letter are not significantly different.

Table (3) Changes in serum lipid profile of normal, alloxan diabetic and alloxan diabetic treated rats for 4 weeks

\begin{tabular}{|c|c|c|c|c|c|c|c|c|c|c|c|c|}
\hline \multirow[t]{2}{*}{$\begin{array}{r}\text { parameter } \\
\text { Plant }\end{array}$} & \multicolumn{2}{|c|}{$\begin{array}{l}\text { triglycerides (mg } \\
\text { /dl) }\end{array}$} & \multicolumn{2}{|c|}{$\begin{array}{l}\text { cholesterol (mg } \\
\text { /dl) }\end{array}$} & \multicolumn{2}{|c|}{$\begin{array}{l}\text { HDL-cholesterol } \\
\text { (mg/ dl) }\end{array}$} & \multicolumn{2}{|c|}{$\begin{array}{l}\text { LDL-cholesterol } \\
\text { (mg/ dl) }\end{array}$} & \multicolumn{2}{|c|}{$\begin{array}{l}\text { HDL / Total } \\
\text { cholesterol } \\
\text { ratio }\end{array}$} & \multicolumn{2}{|c|}{$\begin{array}{l}\mathrm{LDL} / \mathrm{HDL} \\
\text { cholesterol } \\
\text { ratio }\end{array}$} \\
\hline & $\mathrm{N}$. & A.D. & $\mathrm{N}$. & A.D. & $\mathrm{N}$. & A.D. & $\mathrm{N}$. & A.D. & N. & A.D. & N. & A.D. \\
\hline Control & $\begin{array}{l}67.19 a \\
\pm 1.71\end{array}$ & $\begin{array}{l}106.09 \\
\pm 3.59\end{array}$ & $\begin{array}{l}85.37^{\mathrm{ab}} \\
\pm 2.43\end{array}$ & $\begin{array}{l}111.14 \\
\pm 3.07\end{array}$ & $\begin{array}{l}34.32^{c} \\
\pm 1.04\end{array}$ & $\begin{array}{l}21.53 \\
\pm 2.03\end{array}$ & $\begin{array}{l}33.31^{\mathrm{ab}} \\
\pm 2.16\end{array}$ & $\begin{array}{l}57.28 \\
\pm 0.98\end{array}$ & 0.402 & 0.192 & 0.971 & 2.660 \\
\hline Green tea & $\begin{array}{l}68.6 \mathrm{a} \\
\pm 1.48\end{array}$ & $\begin{array}{l}91.04 \\
\pm 1.64\end{array}$ & $\begin{array}{l}85.44^{\mathrm{ab}} \\
\pm 2.07\end{array}$ & $\begin{array}{l}87.44^{\mathrm{a}} \\
\pm 1.95\end{array}$ & $\begin{array}{l}35.49^{\mathrm{bC}} \\
\pm 2.16\end{array}$ & $\begin{array}{l}27.28 \\
\pm 1.08 \\
\end{array}$ & $\begin{array}{l}31.03^{\mathrm{C}} \\
\pm 1.44\end{array}$ & $\begin{array}{l}34.27^{a} \\
\pm 1.62\end{array}$ & 0.415 & 0.312 & 0.874 & 1.256 \\
\hline Sage & $\begin{array}{l}67.84 a \\
\pm 0.98\end{array}$ & $\begin{array}{l}83.31 \\
\pm 2.77\end{array}$ & $\begin{array}{l}84.04^{\mathrm{DC}} \\
\pm 1.68\end{array}$ & $\begin{array}{l}86.13^{\mathrm{ab}} \\
\pm 2.07\end{array}$ & $\begin{array}{l}36.7^{\mathrm{ab}} \\
\pm 1.45\end{array}$ & $\begin{array}{l}30.75^{\mathrm{a}} \\
\pm 1.59\end{array}$ & $\begin{array}{l}31.51^{\mathrm{DC}} \\
\pm 1.44\end{array}$ & $\begin{array}{l}33.91^{\mathrm{a}} \\
\pm 1.55\end{array}$ & 0.437 & 0.357 & 0.857 & 1.103 \\
\hline Ginseng & $\begin{array}{l}66.39 a \\
\pm 1.77\end{array}$ & $\begin{array}{l}74.38 \\
\pm 5.91\end{array}$ & $\begin{array}{l}82.37^{\circ} \\
\pm 2.05\end{array}$ & $\begin{array}{l}84.10^{\mathrm{DC}} \\
\pm 1.76\end{array}$ & $\begin{array}{l}38.04^{\mathrm{a}} \\
\pm 1.65\end{array}$ & $\begin{array}{l}31.53^{\mathrm{d}} \\
\pm 1.32\end{array}$ & $\begin{array}{l}28.44 \\
\pm 1.58\end{array}$ & $\begin{array}{l}31.06^{c} \\
\pm 1.51\end{array}$ & 0.462 & 0.375 & 0.748 & 0.985 \\
\hline $\begin{array}{r}\text { L.S. D } \\
\mathrm{P}<0.05\end{array}$ & 2.5104 & & 2.5372 & & 1.8518 & & 1.8652 & & & & & \\
\hline $\begin{array}{r}\text { L.S. D } \\
P<0.01\end{array}$ & 3.3588 & & 3.3947 & & 2.4776 & & 2.4955 & & & & & \\
\hline
\end{tabular}

N : Normal A.D. : Alloxan Diabetic

Values given as mean of 6 rats \pm SD.

Means with the same letter are not significantly different. 


\section{Gehan S. Moram}

\section{تأثير المستخلصات المائية لبعض النباتات على الجرذان المصابة بمرض البول السكرى المستحدث بمادة الأللوكسان}

\section{جيهان صالاح الدين مرام قسم الكمياء الحيوية والتغذية - كلية البنات - جامعة عين شنمس - القاهرة - مصر.}

تم فن هذا البحث دراسة تأثير بعض المستخلصات المائية من نباتات الشاى الأخضر والمريمية والجنسنج على الحساسية للأنسولين في الجرذان المصابة بمرض البول السكرى المستحدث بواسطة مادة الأللوكسان. وقد استخدمت في هذه التجربة 48 فأراً مقسمة الى بحموعتين (24 فأراً سليما و24 فأراً مصابا بمرض البول السكرى)

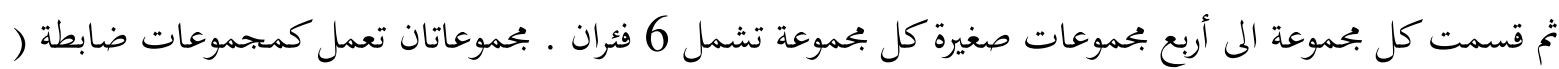
مجموعة شليمة وبحموعة مصابة بالسكر ) أما باقى المجموعات فقد تناولت جرعات من المستخلصات المائية لنباتات الشاى الأخضر والمريمية والجنسنج كل على حدة يوميا لمدة 4 أسابيع. ولقد تناولت هذه الدراسة معرفة تأثير المستخلصات المائية لمذه النباتات على مستوى السكر فن الدم ونسبة الأنسولين في البلازما والكوليسترول والملسريدات الثلاثية والبروتينات الدهنية عاليةالكثافة ومنخفضة الكثافة بالإضافة الى تأثير هذه النباتات على جليكوجين الكبد ونشاط بعض الأنيمات مثل انزيمات الترانس أمينيز و الجلوكوز - 6- فوسفاتينيز والفوسفاتيز القلوى .

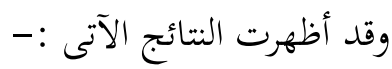

انخفاض ملموس فن مستوى سكر الدم وارتفاع فن محتوى جليكوجين الكبد وزيادة فن نسبة الأنسولين فن المجموعات المصابة بالسكر والمعالجة بمستخلصات النباتات في هذه الدراسة بالمقارنة بالمحموعة المصابة بمرض البول السكرى والغير معالجة.

كما أظهرت النتائج ان جميع دهنيات الدم ( الجلسريدات الثلاثية ونسبة الكوليسترول الكلى والبروتينات الدهنية منخفضة الكثافة) وأيضا نشاط إنزيمات تمثيل الجلوكوز (جلوكوز - 6- فوسفاتيز و انزيمات الترانس أمينيز والفوسفاتيز القلوى) نقصا معنويا في المحموعات المصابة بمرض البول السكرى والمعالجة بمستخلصات النباتات موضوع الدراسة بالمقارنة بالمحموعة المصابة بالسكر وغير المعالجة. أيضا يتضح من نتائج هذا البحث أن مستخلص نباتات الجنسنج كان له أعلى تأثير فن هذه الدراسة عن النباتات الأخرى . 